\title{
AIDS AND SEXUALITY EDUCATION IN THE PHYSIOTHERAPY CURRICULUM
}

\section{INTRODUCTION}

Since the first reports in the early 1980s, acquired immune deficiency syndrome (AIDS) is spreading inexorably across the African continent. AIDS is essentially a sexually transmitted disease, and the causative virus is the human immunodeficiency virus (HIV). In South Africa, the prevalence of AIDS poses a challenge. Records suggest that there are about five hundred thousand HIV-infected people in the country, and that the response from governmental and non-governmental organisations has not matched the extent of the problem'. Published studies in South Africa suggest a lack of knowledge of the transmission and epidemiology of AIDS, a lack of perceived risk and little evidence of significant change towards safer sexual practices ${ }^{2-3}$.

A number of neurological manifestations have been reported in AIDS patients in Africans ${ }^{4-5}$ and non-Africans ${ }^{56}$. These include progressive polyradiculopathy, cerebrovascular accidents, spinal cord degeneration and peripheral neuropathy. These manifestations are reportedly caused by HIV itself and not by secondary opportunistic infections. It is known that medical rehabilitation personnel (including physiotherapists) are already involved in the care of AIDS patients with or without neurological manifestations.

However, inaccurate knowledge of AIDS, along with anxiety and lear, among health care workers have been well documented. ${ }^{7 \cdot 8} \mathrm{~A}$ study of rehabilitation personnel (including physiotherapists) in Zimbabwe reported that while most of the respondents had accurate knowledge of transmission of HIV, more than half of the subjects $(\mathrm{N}=119)$ expressed fear of becoming infected with the virus. ${ }^{9}$ This influenced their prolessional behaviour in the treatment of AIDS patients. In order to promote accurate knowledge about AIDS, the study recommended that education in the pathophysiology and methods of transmission of HIV and treatment of people with AIDS be included in the undergraduate physiotherapy curriculum in Zimbabwe and other African countries.

At the University of the Western Cape, a set of questionnaires is administered to new first-year students during the annual University orientation programme. The students are informed in writing about the purpose of each questionnaire, and their rights to refuse to divulge any information requested. Each questionnaire is completed anonymously to maintain confidentiality. One of the questionnaires is a validated 30 item questionnaire which measures knowledge of AIDS and attitudes towards people with AIDS and homosexual persons. ${ }^{10}$ Currently, there is a dearth of information on the impact of AIDS on physiotherapists and physiotherapy services in South Africa. Therefore the aim of this study was to evaluate the available data on the knowledge and attitudes of physiotherapy students in the University of the Western Cape regarding AIDS. The outcome of the study was intended to establish the extent of the students' knowledge deficits, and to provide data to inform curriculum development in physiotherapy education.

\section{METHOD}

Data supplied by three groups of prospective lirst-year physiotherapy students in 1991 ( $N=35), 1992$ $(\mathrm{N}=28)$ and $1993(\mathrm{~N}=41)$ were retrieved from the data bank which contained information on all first-year students who attended the orientation programme in the specified period. The prospective students indicated that they desired to study physiotherapy but not all of them were admitted into the programme. Only 19, 27 and 30 students respectively registered for physiotherapy in 1991, 1992 and 1993. Only questions which were responded to by most of the subjects over the three years were considered. Thus responses to only 20 items on the 30 -item questionnaire (Tables I \& II) were analysed.

The students who were admitted into the physiotherapy programme in 1993 are currently in the fourth year of training. In order to evaluate any difference between their level of knowledge and attitudes in the first and fourth years of training, the 20-item questionnaire was readministered to this group of students. An additional question was included which assessed willingness to give physiotherapy treatment to a patient with AIDS.

The information retrieved included sociodemographic items, live items on attitudes towards people with AIDS and fifteen items measuring knowledge about the causes of AIDS and mode of transmission of the HIV virus. All items testing attitude and knowledge were rated as "True", "False", and "Don't Know". Levels of anxiety concerning contact with a person with AIDS were measured on a 3point Likert-type scale, with a score of 1 reflecting no anxiety, and a score of 3 reflecting much anxiety. In addition, there were

\section{ABSTRACT}

The need for physiotherapy in the multidisciplinary management of patients with AIDS is generally acknowledged. Physiotherapists should understand the disease, and develop appropriate attitudes towards individuals with AIDS. Data obtained from questionnaires completed at the University of the Western Cape by prospective physiotherapy students between 1991 and 1993, on knowledge of and attitudes about AIDS, were analysed. The same questionnaire was re-administered to a group of physiotherapy students completing their fourth-year of study. Although most of the students indicated accurate knowledge about AIDS, their attitudes were uncertain. Students expressed anxiety about contact with persons with AIDS. The findings suggest the need for the inclusion of AIDS education in the physiotherapy education curriculum at the University of the Western Cape. 
three 9-category items which sought information concerning where the respondent first heard about sexual intercourse, AIDS and the use of condoms. Finally there were two questions relating to the sexual behaviour of the respondents. The retrieved data were collated and frequencies for all variables reported in percentages.

\section{RESULT}

The mean age of the respondents in the three groups of prospective physiotherapy students was 19.7 years $(\mathrm{scl}=1.0), 21.8$ years $(\mathrm{sd}=\mathrm{l} .1)$, and 18.4 years $(\mathrm{sd}=1.8)$ respectively. All were unmarried. Over 34\% of all the respondents $(N=104)$ had already had sexual intercourse before admission 10 the University. Fifteen respondents (14.4\%) were undecided about whether they would have sex with a person known to have been infected with a sexually transmitted disease (STD), though 83 respondents $(79.8 \%)$ would not. The remaining six indicated readiness to have sex with a partner known to have been infected with a sexually transmitted disease.

The respondents' first learning exposures to AIDS were primarily through the mass media $(32.7 \%)$, reading $(28.8 \%)$, and through information received from their high school guidance counsellors (18.3\%). Similarly, the respon- dents' first learning exposures to sexual intercourse were through reading $(29.8 \%)$, parents $(20.2 \%)$ and guidance counsellors (15.4\%). First learning exposures to the use of condoms were from friends (42.3\%), guidance counsellors $(20.2 \%)$ and through reading (15.4\%).

In terms of attitudes to people with AIDS, most of the respondents had a positive attitude (Tablel)

The respondents' level of knowledge about AlDS is shown in Table 11. About $65 \%$ of the 104 respondents gave correct responses while about 20\% indicated "don't know". The mean level of anxiety about contact with a person with AIDS was highest among the 1993 cohort. Respondents had a mean score of $2.93 \quad(\mathrm{scl}=1.11$; $\mathrm{N}=41$ ), while in 1991 and 1992 , the mean scores were 1.71 ( $\mathrm{sd}=0.62, \quad \mathrm{~N}=35) \quad$ and 1.71 ( $\mathrm{sd}=0.66 ; \mathrm{N}=28$ ) respectively.

In re-administering the questionnaire to current fourth-year students, data was obtained from 15 (out of a total of 24) students Eleven students $(73.3 \%)$ indicate that they would not readily have sex with a person known to have been infected with a sexually transmitted disease. The remaining 4 students (26.7\%) were undecided. In testing the level of knowledge about AIDS, the average

TABLE I

Respondents' attitudes towards people with AIDS (1991-1993; $n=104$ )

\begin{tabular}{|c|c|c|c|}
\hline & TRUE & FALSE & DON'T KNOW \\
\hline & $\%$ & $\%$ & $\%$ \\
\hline $\begin{array}{l}\text { AIDS is God's punishment against } \\
\text { homosexual people }\end{array}$ & 14.4 & 50.0 & $26.0 \quad(n=94)$ \\
\hline $\begin{array}{l}\text { If my housemate/roommate had } \\
\text { AIDS, I will ask him/her to move out }\end{array}$ & 20.2 & 54.8 & $24.0(n=103)$ \\
\hline $\begin{array}{l}\text { Students who have AIDS should } \\
\text { not be allowed to attend classes } \\
\text { in this University }\end{array}$ & 17.3 & 69.2 & $8.7 \quad(n=99)$ \\
\hline $\begin{array}{l}\text { Adults who contract AIDS get } \\
\text { pretty much what they deserve }\end{array}$ & 12.5 & 63.5 & $21.2(n=101)$ \\
\hline $\begin{array}{l}\text { People with AIDS should be } \\
\text { quarantined }\end{array}$ & 12.5 & 52.9 & $33.7(n=103)$ \\
\hline
\end{tabular}

Note: The sample sizes vary slightly because information was missing for some items

number of students who gave correct responses was 12 (Table IV).

The level of anxiety expressed about contact with a person with AIDS showed a mean score of 1.73 ( $\mathrm{sd}=0.57)$. Four respondents (26.6\%) were ready to give hydrotherapy, in a pool, required in the treatment of a patient with AIDS, but 10 respondents (66.7\%) were undecided.

\section{DISCUSSION}

\section{Attitudes}

The attitudes of the respondents can affect the quality of patient care. It seems few respondents had negative attitudes towards people with AIDS (Table 1). However an appreciable number of respondents were undecided about their attitudes. Adding the number of respondents with negative attitudes to those who were undecided, there appears to be a sizeable number of the prospective physiotherapy students who had negative attitudes towards people with AIDS. It would seem that the attitude of fourth-year students had improved compared to those expressed by this cohort in 1993 but a few students expressed uncertainty about their attitudes. The uncertainties in attitudes expressed in this study is similar to those reported among rehabilitation personnel in Zimbabwe ${ }^{9}$, occupational therapy students in the US ${ }^{11}$, and prospective students in Social Work at the University of the Western Cape. ${ }^{10}$

\section{KNOWLEDGE}

Most of the respondents gave correct responses to the statements regarding the causes of AIDS and mode of transmission of the HIV virus. The percentage who gave correct responses was $48.6 \%$ in $1991,75.0 \%$ in 1992 , and $73.2 \%$ in 1993. Respondents in this study seem to have a higher level of knowledge about AIDS than prospective students in Social Work. ${ }^{10}$ The percentage who reflected correct responses among prospective students in Social Work was $46.6 \%$ in $1991,57.4 \%$ in 1992, and $63.8 \%$ in 1993.

When the questionnaire was readministered to fourth-year physiotherapy students in 1996, $80 \%$ 
gave correct responses, which was an improvement when compared with 1993. In 1996, there was also a decrease in the level of anxiety about contacl with a person with AIDS. However, the decrease in anxiety was not reflected in the willingness of the fourth-year students to give hydrotherapy in a pool for the rehabilitation of a patient with AIDS

An appreciable number of the respondents $(34 \%)$ had already had sexual intercourse at the time they were admitted to the University. Fifteen respondents (14.4\%) were uncertain whether they would have sex readily with a partner known to have been infected with a sexually transmitted disease in the past. A comparison of the 1993 prospective students $(\mathrm{N}=41)$ and the same cohort of fourth-year physiotherapy students $(N=15)$, showed that $14.6 \%$ in 1993 , and $26.7 \%$ in 1996 were undecided about having sex with a partner known to be infected with a sexually transmitted disease. For most of the prospective students, the major sources of first-learning exposure about AIDS, sexual intercourse and safe sexual practices were through reading materials, the media, and guidance counsellors in high schools. The University therefore faces a challenge to find ways of disseminating relevant information about healthy lifestyles to new students.

Attitudes expressed by the prospective and current physiotherapy students to AIDS, coupled with the uncertainty about safe sexual practices, as well as the learning resources used, suggest an urgent need for the inclusion of AIDS and sexuality in the physiotherapy curriculum. Such material will assist in orienting the students towards a healthy lifestyle, as well as preparing them to offer treatment to patients with AIDS by improving their level of knowledge and attitudes towards AIDS. Such material may not be limited to first year students but should be reinforced at every stage in the physiotherapy education programme. The same material may also be useful for students in other faculties in the University.

\section{CONCLUSION}

The prevalence of AIDS in South Africa poses a challenge to health professionals. While the data reported here represent information from a limiled sample, it does suggest that improving the level of knowledge and the attitudes towards AIDS among physiothera- py students may be one of the steps which would assist in combating prejudice, and preparing the students to work with AIDS patients. Based on the information presented here, it is recommended that a course on AIDS and sexuality be included in the undergraduate physiotherapy education curriculum at the University of the Western Cape.

\section{TABLE |I \\ Respondents' knowledge about AIDS (1991-1993, n=104)}

\begin{tabular}{|c|c|c|c|c|}
\hline & TRUE & FALSE & \multicolumn{2}{|c|}{ DON'T KNOW } \\
\hline & $\%$ & $\%$ & $\%$ & \\
\hline $\begin{array}{l}\text { Health workers and others who } \\
\text { care for people with AIDS are } \\
\text { likely to contract AIDS themselves }\end{array}$ & 19.2 & 56.7 & 19.2 & $(n=99)$ \\
\hline $\begin{array}{l}\text { The country's blood supplies are } \\
\text { probably contaminated by the HIV } \\
\text { virus at the present time }\end{array}$ & 27.9 & 44.2 & 27.9 & $(n=104)$ \\
\hline $\begin{array}{l}\text { You can contract AIDS by giving } \\
\text { blood }\end{array}$ & 37.5 & 46.2 & 16.3 & $(n=104)$ \\
\hline $\begin{array}{l}\text { Most people who have HIV virus } \\
\text { in their blood will eventually } \\
\text { develop AIDS }\end{array}$ & 36.5 & 24.0 & 33.7 & $(n=98)$ \\
\hline $\begin{array}{l}\text { It is impossible to contract AIDS } \\
\text { without an exchange of body fluids }\end{array}$ & 58.7 & 16.3 & 25.0 & $(n=104)$ \\
\hline $\begin{array}{l}\text { A person can have no symptoms } \\
\text { and still be infectious }\end{array}$ & 74.0 & 2.9 & 21.2 & $(n=102)$ \\
\hline $\begin{array}{l}\text { Intravenous drug users are in the } \\
\text { high risk group for contracting AIDS }\end{array}$ & 61.5 & 6.7 & 22.1 & $(n=94)$ \\
\hline \multicolumn{5}{|c|}{$\begin{array}{l}\text { If one is in contact with a person with the HIV virus, } \\
\text { there is a high risk of contracting AIDS by: }\end{array}$} \\
\hline sharing coffee cups & 1.9 & 77.9 & 10.6 & $(n=94)$ \\
\hline contact with their blood & 83.7 & 1.0 & 5.8 & $(n=94)$ \\
\hline touching their clothing & 5.8 & 86.5 & 2.9 & $(n=99)$ \\
\hline using the same toilet & 11.5 & 57.7 & 2.2 & $(n=94)$ \\
\hline sexual intercourse & 98.1 & 0.0 & 1.0 & $(n=103)$ \\
\hline touching the genitals with the hands & 12.5 & 39.4 & 38.5 & $(n=94)$ \\
\hline kissing on the lips & 6.7 & 65.4 & 18. 3 & $(n=94)$ \\
\hline kissing on the cheek & 1.9 & 87.5 & 10.6 & $(n=104)$ \\
\hline
\end{tabular}


GLITE

\section{Recruitment Specialists Physiotherapists}

For long and short term positions throughout Great Britain

- Excellent Rates of Pay

- Regular Bonus Schemes

- Prompt Weekly Payment

- Proffesional Registration Cash Back

- Free Personal Tax Advice
- Assistance with Bank Account and National Insurance

- Subsidised Training Courses

- Free Malpractice Insurance

- Elite Social \&

Recreational Club

For a most efficient and personalised service contact

Johan Bosch

P.O. Box 53

White River 1240

Tel/Fax:(13) 7512235/66
Dalmari van Zyl

P.O. Box 512, Bethlehem 9700

Cell phone: 0832699033

Fax: 05842288

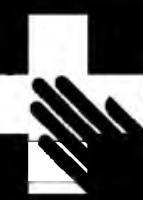

ELITE Medical Services Ltd

4-6 Bury Street, St James's, London SWIY 6AB

Tel: (0171) 8395000 (10 lines) Fax: (0171) 925 2610/1/2

3 mins walk from Piccadilly and Green Park Stations

Raising Standards in Health and Social Care

\section{USA Sponsorship Programme} for Physiotherapists

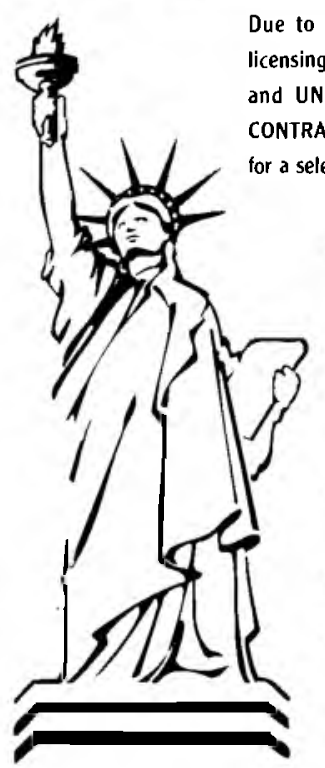

Due to developments in the healthcare market and in censing regulations in the USA, therapists holding a FULL CICTED license prior to taking up their NIRACT are at an advantage. Therefore our programme

* One week ALL EXPENSES PAID TRIP TO BOSTON, USA to sit the NPT Exam

* FULL STUDY PROGRAMME and REVIEW SEMINAR

* CUSTOMISED SALARY and BENEFITS PACKAGE

* 18 /24 month CONTRACTS

* HIB Visa / GREEN CARD

For more Information phone: Joanne on (021) 8516114 (9am - 5pm) or Kathy on (021) $8872281(6 \mathrm{pm}-8 \mathrm{pm})$

Blandford House, 67 Caledon St., P.0. Box 766, Somerset West 7129 Tel: (021) 8516114 Fax: (021) 8525508 email: ogpsa@iafrica.com

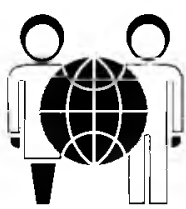

O'GRADY PEYTON

\section{REFERENCES}

I Yach D. Towards health for all South Africans. South African Medical Journal 1994;84,250-253

2. Padayachee GN. Evaluation of AIDS prevention programmes - the key lo success. South African Medical Journal 1991;80,310-311.

3. Friedland RH, Jankelowitz SK, De Beer M, De Klerk C, Khoury U, Csizmadia T, Padayachee GN, Levy S. Perceptions and knowledge about the acquired immunodeficiency syndrome among students in University residences. South African Medical Journal 1991,79,149-154.

4. Amosun SL, Gatsi LT, Mawere JH. Neurological manilestations in A1DS: Implications for rehabilitation. South African Journal of Physiotherapy 1995;51:45-47

5. Carneiro AV, Ferro J, Figueiredo C, Costa L, Campos J, de Padua F Herpes zoster and contralateral hemiplegia in an African infected with HIV-1. Acta Medica Portuguesa 1991:4:91-92

6. Leger JM, Henin D, Belec L, Mercier B, Cohen L, Bouche P, Hauw JJ, Brunel P. Lymphoma-induced polyradiculopathy in AlDS: Two cases. Journal of Neurology 1992;239:132-134

7. Lewis CE, Freeman HE, Corey CR. AIDS-related compelence of California's primary care physicians. American Journal of Public Hcalth 1987;77:975-799.

8. Searle ES. Knowledge, attitudes and behaviour of health professionals in relation to AlDS. Lancet 1987;i:26-28

9. Gatsi LT, Amosun SL, Mhlanga FG. Rehabilitation personnel and AIDS in Zimbabwe: Knowledge, atitudes and prolessional behaviour. Physiotherapy Theory and Practice 1994;10:95-102.

10. Nicholas L, Orr NM. AlDS Knowledge and attitudes towards homosexuals and people with AIDS of prospective black first-year Social Work Universily students: 1991-1993. Social Work 1995; 3 1:90-96.

11. Vincent TA, Schkade JK. Knowledge and attitudes of occupational therapy students regarding AIDS. American Journal of Occupalional Therapy 1990;44,205-210.

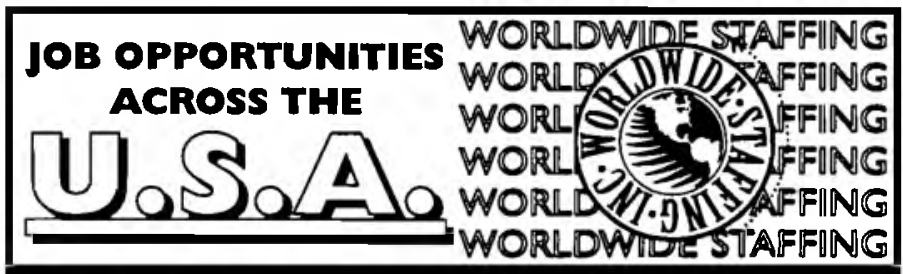

SPECIAUSTS IN PLACING THERAPISTS FROM AROUND THE WORID NTO ROSITIONS ACROSS THE U.S.A.

Our unprecedented full service approach ensures that all applications are completed with speed, quality \& value

Our computerized database allows us access to the type of work you are looking for and the geographic location you desire

Your recruiter will work closely with both you and your new employer to ensure that your needs are met

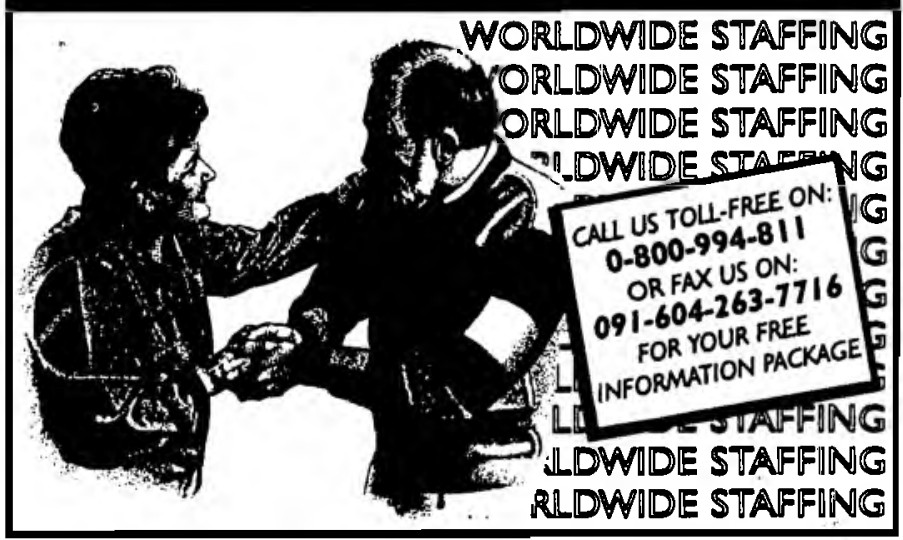

